\title{
UNILATERAL UNION CONTROL OF HIRING HALLṠ: THE WRONG AND THE REMEDY
}

ONE function of the federal labor laws is to prevent "discrimination in regard to ... conditions of employment to encourage or discourage membership in any labor organization." 1 Under the Wagner Act the primary object was to prevent employer discrimination designed to interfere with union concerted activities. ${ }^{2}$ The Taft-Hartley Act extends the Wagner Act by prohibiting union discrimination which adversely affects the employment conditions of nonunion workers. ${ }^{3}$ As a result of this extension, the legitimacy of several traditional practices and institutions has been put in question. Practices in which control over certain working conditions of employees has been delegated to the union must now be examined to determine whether the union in the exercise of its delegated powers is discriminating for the purpose of encouraging union membership.

This problem is a particularly delicate one in the case of unilateral union control over hiring through hiring halls. For unfettered control gives the union an inordinate degree of power with which to encourage union membership. On the other hand, the hiring hall is a long established institution upon which the employer, union, and workers heavily depend in the construction and maritime industries for stable employment practices. Thus, not only must effective measures be devised to guard against abuse of the union's enormous power, but such measures must also be formulated with an eye to preserving the hiring hall as a working institution.

Recent NLRB decisions in the general area of union discrimination seem ill-suited to the task of meeting and accommodating these conflicting demands. The Board's decisions evidence an ad hoc approach to the problem, with only a token attempt to apply the legislative scheme set forth in sections 7, 8, and 9 of Taft-Hartley. This Comment will attempt to formulate a more satisfactory approach to the hiring hall problem by focusing more closely on the provisions of the statute and the legislative intent behind them. It will discuss the present Board policies, analyze the applicable Taft-Hartley provisions, and apply them to the unilateral union control situation.

\section{Hiring Halls}

\section{NLRB Policy: Sone Contradictrons}

The development of the hiring hall in the casual labor industries was marked by a lengthy history of labor-management strife. Because the seasonal

1. National Labor Relations Act, § 8(3), 49 Stat. 452 (1935) (now § 8(a) (3), 61 Stat. 140-41 (1947), 29 U.S.C. $\$ 158$ (a) (3) (1958)) [hereinafter all sections of the Wagner and Taft-Hartley Acts are cited as the LMRA followed by the Taft-Hartley statutory section and the U.S.C. citation].

2. An attempt to add union unfair labor practices in 1935 was rejected as defeating the very object of the bill-to promote union organization and collective bargaining. See S. REP. No. 573, 74th Cong., 1st Sess. 16 (1935).

3. LMRA \& $8($ b) (2), 29 U.S.C. \& 158(b) (2) (1958). 
and fluctuating nature of projects in these industries required each employer to maintain a standing labor surplus, the creation of centralized hiring halls to allocate trained personnel was a natural development. ${ }^{4}$ In the maritime and longshore industries, employer-dominated halls were the first to develop. ${ }^{5}$ As union organizational attempts began, the employer hiring halls were used as an anti-union device to exclude union adherents. ${ }^{6}$ To combat this influence, unions in these industries sought to oust employers from control of the hiring hall mechanism, and were for the most part successful soon after passage of the Wagner Act. ${ }^{7}$ In the construction industry, because of the large number and turnover of contractors operating in no fixed locale, the local union proved the natural employment clearing house from the start. $^{8}$ In both cases, upon establishing control of a hiring hall, the union, like the employer before it, used the hall to discriminate against its opponents through preferential hiring. Nonunion members were refused employment until all union members had been hired. ${ }^{\circ}$

The normal exclusive hiring hall agreement provides that the union has from 24 to 48 hours to refer all the workers requested by the employer who may accept or reject them as he pleases. In fulfilling this function the union is unilaterally responsible for classifying the employees in job categories and selecting them for referral. ${ }^{10} \mathrm{~A}$ variation in some industries, known as the nonexclusive hiring hall, gives the employer the option of hiring from the union or elsewhere. ${ }^{11}$ The following analysis will be directed solely to the exclusive hiring hall.

Union hiring halls were not challenged under the Wagner Act. For one reason, there were no union unfair labor practices. Although the employer

4. Goldberg, The Marttinfe Story 277-78 (1958) [hereinafter cited as Goldberg]; Sherman, Legal Status of the Building and Construction Trades Unions in the Hiring Process, 47 GEo. L.J. 203, 203-06, 212 (1958) ; Fenton, The Taft-Hartley Act and Union Control of Hiring-A Critical Exannination, 4 VILL. L. Rev. 339, 341-46 (1959); Comment, 60 YALE L.J. 673, 676-77 (1951).

Unilateral union control of job rights also exists in certain craft industries such as printing. The International Typographical Union usually controls not only hiring but many other conditions of employment. PORTER, JoB Property RIGHTs 11-16 (1954).

5. Goldberg 12-13, 17, 106-08; Larrowe, Maritime Labor Relations on the Great LAKES 36-37, 39, 42-43, 59 (1959) [hereinafter cited LARRowe]; Fenton 342.

6. LaRRowe $36-37,42-43,59,65$; GoldBerg $12-13,17,103-18$.

7. Goldberg 134-35, 140-44, 150-62, 277; Fenton, supra note 4, at 342. See also LARROWE 59-65 (still lack control on the Great Lakes).

8. Fenton, supra note 4 , at 344-46.

9. GOLDBERG 25-26, 86-87; sêe, e.g., International Longshoremen's Union, 90 N.L.R.B. 1021, 1049-50 (1950); Maritime Indus. Bd. of Inquiry, 10 Lab. Arb. 449, 456-57 (1948).

10. See, e.g., the contract provision in Mountain Pacific Chapter, 119 N.L.R.B. 883, 894 (1957).

11. GoLDBERG 234. In practice, however, the employer ustually clears all nonreferred applicants with the union, since union men will refuse to work with nonapproved applicants. See Haber \& Levinson, Labor Relations and Productivity in the Building Trades $42-44$ (1956) [hereinafter cited as Haber \& Levinson] ; Rains, Construction Trades Hiring Halls, 10 LAB. L.J. 363, 373 (1959) [hereinafter cited as Rains]. 
could have been held liable for allowing the union to misuse their delegated power to discriminate against nonmembers, ${ }^{12}$ the thrust of the Wagner Act was to protect employee concerted activity from the employer and not the individual from the misuse of union power. ${ }^{13}$ Further, since the closed shop was valid, the hiring hall was considered a legitimate device for enforcing it. ${ }^{14}$

The Taft-Hartley Act outlawed the closed shop and changed the thrust of federal labor law to protect the individual from the union as well as from the employer. ${ }^{15}$ Congressional investigation had revealed that not only was the closed shop used to exclude "undesirable" workers, thus dictating the employer's hiring policy, but also that the union's power to expel a member from his job by expelling him from the union was used to enforce union discipline, to eliminate minority factions, or even to satisfy personal whim.16 Section 8(a) (3) replaced the closed shop with the less restrictive "union shop." 17 Any nonunion member is allowed to work for 30 days before being required to join the union, thus freeing the employer's hiring policy. Moreover, a union member cannot be expelled from a union operating a union shop for any offense other than nonpayment of dues. By this latter provision, Congress intended to eliminate the other inequities of the closed shop. ${ }^{18}$ In addition, section 8 (b) (2) makes it an unfair labor practice for the union to cause or attempt to cause an employer to discriminate against any employee for the purpose of encouraging union membership. ${ }^{19}$ Thus the union is in fact governed by section 8(a) (3) whenever its acts cause discrimination prohibited by that section. In line with the congressional intent to abolish the inequities of the closed shop, the Supreme Court in Radio Officers v. $N L R B{ }^{20}$ read unlawful "encouragement of membership" to include not just enrollment on the union books but also encouragement to comply with union policies and to participate in union activities. Since union control of hiring halls gives the union power to "encourage union membership" by

12. See Wallace Corp. v. NLRB, 323 U.S. 248 (1944).

13. See note 2 supra; Ward, "Discrimination" Under the National Labor Relations Act, 48 YALE L.J. 1152 (1939) [hereinafter cited as Ward].

14. See Fenton, supra note 4, at 343; of. PorTer, op. cit. supra note 4, at 57. The closed shop was legalized by the Wagner Act, § 8(3), 49 Stat. 452 (1935).

15. The amendments to $\S 7$ and the addition of union unfair labor practices clearly show this change in policy. Compare the Wagner Act $\S \S 7,8,49$ Stat. 452 (1935), with LMRA $\S 87,8,29$ U.S.C. $\S \S 157,158$ (1958). See also Cox, Some Aspects of the Labor Management Relations Act, 1947, (pt. 1), 61 HARv. L. Rev. 1, 24-25, 44 (1947).

16. See Millis, From the Wagner Act to.Taft-Hartley 277-78, 435 (1950); 93 Cong. Rec. 3836 (1947) ; S. Rep. No. 1827, 81st Cong., $2 d$ Sess. 12 (1950) ; S. Rep. No. 105, 80th Cong., 1st Sess. 6 (1947).

17. LMRA § 8(a) (3), 29 U.S.C. $\$ 158$ (a) (3) (1958). See generally 93 CoNG. REc. 4885 (1947).

18. See H.R. Rep. No. 245, 80th Cong., 1st Sess. $33-34$ (1947) ; S. Rep. No. 105, 80th

Cong., 1st Sess. 7 (1947).

19. LMRA § \&(b) (2), 29 U.S.C. § 158 (b) (2) (1958).

20. 347 U.S. 17, 39-42 (1954). 
discriminating in the assignment of jobs, the legality of the institution is put in doubt by section 8 (b) (2)..$^{21}$

The NLRB did not face directly the validity of the exclusive union hiring hall until the Mountain Pacific case in $1957 . .^{22}$ The Board analyzed the case in terms of the employer's act of "complete and outright" delegation of control over hiring. It found such delegation to constitute unlawful discrimination encouraging membership in a labor organization, specifically incorporating the broad section 8 (a)(3) interpretation of the Radio Officers case. ${ }^{23}$ "It is reasonable to infer," the Board concluded, that the union will hand out jobs with an eye towards winning compliance with membership obligations, and that the applicants for employment, instead of relying on their skill and experience to get jobs, will seek out ways to "ingratiate themselves with the Union." ${ }^{24}$ In cases such as these, the Board stated, "direct and specific proof of unlawful encouragement" is unnecessary, and the inference may be drawn from the agreement delegating exclusive hiring power to the union. ${ }^{25}$ Rather than outlaw the exclusive hiring hall completely, the Board set out three conditions which, if expressly incorporated in the collective bargaining agreement, would negate the inference of unlawful discrimination. The collective agreement must provide for 1) nondiscriminatory referral, 2) employer right to reject any applicant referred, and 3) posting at the hiring hall of the nondiscriminatory standards of referral. ${ }^{26}$

21. GoLDBERG 222-23, 241-46. The question of legality has become particularly important now that the Board has reversed its Wagner Act practice of not exercising jurisdiction over the $2 \mathrm{t} / 2$ million construction workers-a primary user of the hiring hall. Comment, 60 YALE L.J. 673 \& n.6 (1951). For criticism of Board practices in this respect, see Craig, Hiring Hall Arrangements and Practices, 9 LAB. L.J. 937, 939-43 (1959).

22. Mountain Pacific Chapter, 119 N.L.R.B. 883 (1957). The Board as early as 1948 had invalidated contracts where the employer and union had intended to discriminate. See National Maritime Union, 78 N.L.R.B. 971 (1948), enforced, 175 F.2d 686 (2d Cir. 1949), cert. denied, 338 U.S. 954 (1950). See also International Longshoremen's Union, 90 N.L. R.B. 1021, 1026 (1950) (concurring opinion) ; Pacific Maritime Association, \$9 N.L.R.B. 894 (1950) ; National Maritime Union, 82 N.L.R.B. 1365 (1949) ; American Radio Ass'n, 82 N.L.R.B. 1344 (1949).

23. 119 N.L.R.B. at 895 \& n.5.

24. Id. at 895 .

25. Ibid.

26. These conditions appear to come from the contract approved by the Board in National Union of Marine Cooks (Pacific American Shipowners Ass'n), 90 N.L.R.B. 1099 (1950), the general form of which had been fashioned with the help of Senator Taft in the settling of maritime disputes after passage of the Taft-Hartley Act. Goldberg 234, 244; MILLIS, op. cit. supra note 16 , at 437.

The rule of Montintain Pacific has had a checkered pattern on appeal. It was reversed and remanded by the Ninth Circuit on the ground that the Board had neither made a factual finding of employer-union intent to discriminate nor created, on the basis of its expertise, an evidentiary presumption of discrimination. $270 \mathrm{~F} .2 \mathrm{~d} 425$ (9th Cir. 1959). The doctrine has also been questioned as an arbitrary exercise of rule-making power. NLRB v. E. \& B. Brewing Co., 276 F.2d 594 (6th Cir.), petition for cert. filed, 29 U.S. LAW WEeK 3026 (U.S., July 19, 1960) (No. 211). Two other circuits, however, have approved the rule. 
The Mountain Pacific decision is open to several criticisms. Statutory authority for the "inference" of discrimination from exclusive hiring hall agreements seem nonexistent. Even if the presumption were accurate, one may wonder whether the inclusion of three clauses in a collective agreement will change the likelihood of discrimination. And, of course, the conditions imposed, like the inference of discrimination itself, are not grounded upon any statutory provision or policy.

\section{Seniority}

The ad hoc nature of Mountain Pacific is put in relief by the Board's contradictory position in Pacific Intermountain Express. ${ }^{27}$ There the Board found that delegation to the union to set the terms of seniority rights and to settle seniority disputes was a violation of 8 (a) (3). The Board reasoned that the employer had special knowledge of the employment history relevant to seniority whereas the union's knowledge would be relevant only to discrimination. From this it concluded, "We can see no basis for presuming that when an employer delegates to a union the authority to determine the seniority of its employees ... such control will be exercised by the union in a nondiscriminatory manner." ${ }^{28}$ This remains true, the Board stated, even though one of the contracts involved contained a clause similar to the first Mountain Pacific condition-the settlement of seniority disputes was to be made without regard to union membership. ${ }^{29}$

One reading of Pacific Intermountain would allow a seniority delegation in certain situations. The Board's emphasis upon the union's lack of special qualifications to administer seniority rights seems to suggest that if the union could show some valid reason for the delegation, such as special union knowledge of employment history not available to the employer, the Board would no longer have a "basis for presuming" discrimination as the only possible motive.

An exception of this nature, however, has not materialized. In industries such as over-the-road trucking, the union often has better knowledge of an employee's employment record. ${ }^{30}$ Further, where an employer has proved incompetent or used the seniority list to discriminate against union members, the union may well have a valid interest in bargaining for exclusive control. In addition, the employer may contend that the union, as the employees' repre-

Local 357, Teamsters Union v. NLRB, 275 F.2d 646, 647 (D.C. Cir. 1960), cert. granted, 363 U.S. 837 (1960) (Nos. 64 and 85, 1960 Term) ; NLRB v. Local 176, United Bhd. of Carpenters, 276 F.2d 583, 585-86 (1st Cir. 1960).

27. 107 N.L.R.B. 837 (1954).

28. Id. at 845 .

29. Id. at $845-46$ ("[W]e also conclude that, the inclusion of a statement . . . that seniority will be determined without regard to union membership is not by itself enough to cure the vice of giving to the union complete control over the settlement of a 'controversy' with respect to seniority.").

30. See Lexter, The Trucking Industry 162-64 (1957). 
sentative, is best suited to settle touchy disputes over job priority. ${ }^{31}$ Despite these possible justifications, however, the Board has never been swayed to find it no longer has a "basis for presuming" discrimination. ${ }^{32}$ One can only conclude, therefore, that the holding in Pacific Intermonntain compels the presumption of discrimination no matter what other arguments for exclusive delegation are put forward. Nor does it appear that practical reasons for delegation, such as the need to rationalize hiring in the casual labor industries can overcome the prohibition against discrimination once it is presumed to exist. The Board has never indicated, not even in Monntain Pacific, that discrimination is to be condoned where special reasons for delegation exist. 33 Thus, Pacific Intermountain implies an absolute bar on the delegation of unilateral control over seniority, and by analogy, unilateral control over any other condition of employment to the union.

There is nothing in the NLRB's analysis of these problems to distinguish unilateral union control of seniority from similar control of hiring. ${ }^{34}$ Indeed, the hiring hall is in many ways a substitute for the institution of seniority in the casual labor industries. Where employment is not a continuous association with one employer, the employee's job security within the industry is governed by his rank in the hiring hall, which determines his job classification and

31. See Sayles, Seniority: An Internal Union Problem, 30 Harv. Bus. Rev., No. 1, 55 (1952). Some employers hold this same point of view with respect to hiring. Hearings an S. 1973 Before the Subcommittee on Labor and Labor-Management Relations of the Senate Conmittee on Labor and Public Welfare, 82d Cong., 1st Sess. 173-74 (1951).

32. See NLRB v. Teamsters Union, 225 F.2d 343, 347 (8th Cir. 1955); NLRB v. International Assoc. of Machinists (Menasco Mfg. Co.), 279 F.2d 761, 765-66 (9th Cir. 1960) ; Armour \& Co., 123 N.L.R.B. 1157 (1959); North East Texas Motor Lines, Inc., 109 N.L.R.B. 1147, 1149 (1954), enforced as modified sub. nom. NLRB v. Local 745, Teamsters' Union, 228 F.2d 702 (5th Cir. 1956) ; Kenosha Auto Transp. Corp., 113 N.L. R.B. 643, 643-44 (1955) ; Kramer Bros. Freight Lines, Inc., 121 N.L.R.B. 1461, 1463 (1958) ; Chief Freight Lines Co., 111 N.L.R.B. 22, 34 (1955), enforced sub. nom. NLRB v. Local 886, Teamsters' Union, 235 F.2d 105 (10th Cir. 1956). See also Minneapolis Star \& Tribune Co., 109 N.L.R.B. 727, 728-29, 737-38 (1954) (union both compiled seniority list, i.e., established the common rule, and settled disputes).

33. See generally Mountain Pacific Chapter, 119 N.L.R.B. 883 (1957). But sec trial examiners report distinguishing Pacific Intermountain. Id. at 906-07.

34. Indeed, prior to Mountain Pacific the Board seemed to be approaching a rule of absolute illegality in hiring hall cases. In Local 542, International Union of Operating Engineers, 117 N.L.R.B. 1863, 1868 (1957), enforcement granted, 255 F.2d 703 (3d Cir. 1958) the Board appeared to hold that any attempt of the union to enforce standards of referral was invalid no matter what type of contract was made with the employer.

Observe the Ninth Circuit's questionable attempt to distinguish hiring halls from seniority by judicious use of the adjective and bland assertion:

It has been held that the Board can announce as a rule, by its finding in a particular case, that a contract provision permitting a Union to settle seniority is illegal and violative of the Act because it tends to encourage union membership. . . .

But a colorless provision for the maintenance of a hiring hall must be differentiated from the provision permitting a Union to settle seniority.

NLRB v. Mountain Pacific Chapter, 270 F.2d 425, 429 (9th Cir. 1959). 
records his total length of service in the industry as a basis for priority in the employment scheme. ${ }^{35}$ In spite of this, a delegation of hiring is legal, and seniority not. This apparent contradiction cannot be explained by reference to the statute, for the presumptions erected in both cases are equally lacking in statutory authority. Indeed, the contradiction is probably attributable to the ad hoc quality of both decisions. Any attempt to bring order to this area, therefore, should probably begin with a closer look at the Taft-Hartley Act itself.

\section{The Taft-Hartley Act}

The machinery set in operation by the National Labor Relations Act-the exclusive bargaining representative, good faith bargaining, unfair labor practices, the NLRB - is designed to foster collective bargaining and the orderly settlement of industrial disputes by the parties involved. ${ }^{36}$ The resultant agreements become the industrial law of the parties and are enforceable under section $301 .^{37}$ There is a policy, therefore, that the institutions and practices established by the parties are valid unless they violate specific provisions of the Act. $^{38}$

\section{Legislative History and Hiring Halls}

If there were a finding that in passing the Taft-Hartley Act Congress specifically intended to invalidate union hiring halls, the Board would have little other choice than to find hiring halls per se illegal. The Board, to support its holding of conditioned legality in Mountain Pacific, relies upon legislative history made by Senator Taft some three years after the act was passed. ${ }^{39}$ Over all, however, Senate Reports and statements by Senator Taft in debates at the time the Taft-Hartley Act was passed suggest a congressional belief that hiring halls inherently discriminate and interfere with employer access to the labor market, and that they should therefore be ruled invalid. ${ }^{40}$ This opinion was

35. See Sherman, supra note 4, at 217-19; Rains 370.

36. See Cox, supra note 15, 274-76.

37. LMRA $\$ 301,29$ U.S.C. $\$ 185$ (1958); see Textile Workers Union v. Lincoln Mills, 353 U.S. 448 (1957).

38. See Cox, Cases on Labor Law 136-37 (4th ed. 1958).

39. 119 N.L.R.B. at 896-97.

40. House Reports and debates do not specify the particular closed shop abuses they intended to eliminate. However, the Report of the Senate Committee which framed the section finally enacted, is quite clear. The principal witness on the closed shop before the Senate Labor Committee was Mr. Almon Roth, an official of the Pacific American Shippers Ass'n, who decried any interference with employer freedom to hire from a free labor market. The Committee Report shows the effect of his testimony:

It is clear that the closed shop which requires preexisting union membership as a condition of obtaining employment creates too great a barrier to free employment to be longer tolerated. In the maritime industries and to a large extent in the construction industry union hiring halls now provide the only method of securing employment. This not only permits unions holding such monopolies over jobs to exact 
based, however, on evidence which indicated that hiring halls had been used to maintain the worst types of closed shops. ${ }^{41}$ As a result, hiring halls and the closed shop were viewed as inseparable institutions, such that the fall of one would naturally include the other. For example, Senator Taft said in the debates, "It [Taft-Hartley] abolishes the closed shop insofar as that means that only members of the union can be employed. This is the hiring hall proposition." 42 Viewed in light of its major premise, this statement demonstrates only that Congress intended to abolish hiring halls which were used to perpetuate closed shops and to discriminate against nonunion employees. The policy underlying such statements would not apply to nondiscriminatory hiring halls. And since subsequent investigations, such as the Taft Report cited in Mountain Pacific, ${ }^{43}$ have concluded that nondiscriminatory hiring halls are possible, the NLRB should analyze each challenged hiring hall separately, invalidating only those which are in fact closed shops.

But even if discrimination is eliminated from the union hiring hall, there is another policy expressed in the legislative history of the 1947 act, namely, that the employer has a nondelegable hiring prerogative with which the closed shop interfered, ${ }^{44}$ and that delegation of this right to the union is illegal. Such an employer right, however, is never clearly articulated as a separate right in

excessive fees but it deprives management of any real choice of the men it hires. Extension of this principle to licensed dock and engine officers has created the greatest problem in connection with the safety of American vessels at sea. (See testimony of Almon E. Roth ....)

S. Rep. No. 105, 80th Cong., 1st Sess. 6-7 (1947). (Emphasis added.) Senator Taft's opening statement in the debates emphasized that 8 (a) (3) is designed to break the union monopoly power over hiring and return it to the employer:

[T] he bill does abolish the closed shop. Perhaps this is best exemplified by the so-called hiring halls on the west coast, where shipowners cannot employ anyone unless the union sends him to them. That has produced a situation ... where there is no discipline. A man may be discharged one day and may be hired the next .... Such an arrangement gives the union tremendous power over the employees; furthermore, it abolishes a free labor market. A man cannot get a job where he wants to get it. He has to go to the union first; and if the union says he cannot get in, then he is out of that particular labor field. Under such circumstances there is no freedom of exchange in the labor market, but all labor opportunities are frozen.

As a matter of fact, most of the so-called closed shops are union shops. There are not very many closed shops. If in a few rare cases the employer wants to use the union as an employment agency, he may do so; there is nothing to prohibit his doing so. But he cannot make a contract in advance that he will only take the men recommended by the tmion.

93 CoNG. REc. 3836 (1947). (Emphasis added.) This last sentence would eliminate the normal exclusive tnion hiring hall. See generally 93 CoNG. REc. 4876-87 (1947).

41. S. Rep. No. 105, 80th Cong., 1st Sess. 6 (1947) ; Hearings on S. 55 \& S.J. Res. 22 Before Committee on Labor and Public Welfare, 80th Cong., 1st Sess. 611-12, 632 (1947).

42. 93 Cong. Rec. 4885 (1947).

43. S. Rep. No. 1827, 81st Cong., 2d Sess. 12-20 (1950).

44. See quotations cited in note 40 supra. 
the legislative history ${ }^{45}$ and is not mentioned in the language of the statute. Rather, it is interwoven as a minor element with the primary congressional concern-the union's power arbitrarily to restrict the labor market. If such restrictive power is eliminated from the hiring hall, only a clear congressional finding and statement of the employer's nondelegable right to hire would warrant union hiring halls being per se invalid.

\section{$\delta(a)(3) \& 8(b)(2)$ - "Discrimination"}

Whatever rights employees may be given under the Taft-Hartley Act, the most effective way for an employer or union to interfere with such rights is to discriminate with regard to conditions of employment against those employees who choose to exercise them. Section 8(a)(3) prohibits such discrimination where the objective is to encourage or discourage an employee in the exercise of certain designated rights-those included in the right of "membership in a labor organization." ${ }^{46}$ The Board in Mountain Pacific and Pacific Intermountain analyzes delegation of control over hiring and seniority in terms of $S(a)(3)$ and concludes that the acts of employer delegation contain "inherent and unlawful encouragement" of union membership. If the holdings of these two cases are to be of general applicability, as the Board obviously intends, ${ }^{47}$ the acts of central importance to the decisions are these acts of employer delegation. Focusing attention on other acts, such as the specific acts of union discrimination found in Mountain Pacific, will not be relevant. The point of the Mountain Pacific decision is to establish per se violations without the need for the additional factual inquiry necessary to establish union acts of discrimination. Further, specific union acts only injure individuals and the remedy might not outlaw the entire institution of union controlled hiring halls. The violation must depend solely on the ruling that employer delegation of control over specific conditions of employment constitutes a discriminatory act capable of forming the basis of an 8 (a) (3) violation.

The leading Supreme Court case interpreting section $8(a)(3)$ is Radio Officers $v$. NLRB, a consolidation of three Board decisions. ${ }^{48}$ The facts of these cases would indicate that discrimination occurs whenever there are two differing standards of job rights, i.e., disparate treatment, being applied to two

45. The primary concern is that the union will not select workers with an eye to productivity. S. REP. No. 1827, 81st Cong., 2d Sess. 13 (1950). Not all employers would agree. Hearings, supra note 31, at 173-74. See also Rains 367-69.

46. LMRA $\S 8($ a) (3), 29 U.S.C. $\$ \$ 158$ (a) (3) (1958). In addition, see LMRA $\$$ 8(b) (2), 29 U.S.C. $\$ 158$ (b) (2) (1958).

47. See K.M. \& M. Constr. Co., 120 N.L.R.B. 1062 (1958) ; Local 324, Hod Carriers Union, 121 N.L.R.B. 508 (1958); Local 715, United Bhd. of Carpenters, 121 N.L.R.B. 543 (1958).

48. 347 U.S. 17 (1954), consolidating NLRB v. International Bhd. of Teamsters, 196 F.2d 1 (Sth Cir. 1952) ; NLRB v. Radio Officers' Union, 196 F.2d 960 (2d Cir. 1952); NLRB v. Gaynor News Co., 197 F.2d 719 (2d Cir. 1952). 
groups of employees. ${ }^{40}$ Normal use of the word "discrimination" implies disparate treatment for any bad purpose. Disparate treatment is prohibited by 8 (a) (3), however, only when it is for the purpose of encouraging or discouraging union membership. Under the Wagner Act, the Board had defined "membership" as the exercise of the rights to union activity protected by section 7,50 and presumably this relationship exists with respect to the present Taft-Hartley provision. Thus the Court in Radio Officers could look to the definition of rights in section 7 to find that section 8 (a) (3) protects not only the right to join, but also the right to be a good, bad, or indifferent member. ${ }^{51}$ In applying this section the Board has not insisted that the unlawfully favored or unfavored groups be carefully distinguished by the disparate treatment. When a whole department in a plant is laid off because it is the origin of disfavored union activity, the fact that nonunion employees are discharged along with the union agitators does not take the act out of 8 (a) (3)..$^{52}$ Nor need the two differing standards be temporally coexistent. In the case of an employer lockout, the disparate treatment is the abrupt change in conditions of employment with the intended objective of discouraging union membership. ${ }^{53}$

49. See 347 U.S. at 24-38. In Teamsters a union member in a nonunion shop was demoted on the seniority list for nonpayment of dues. In Radio Officers a union member was denied employment on the sole ground that he had not obtained union clearance. In Gaynor retroactive pay increases were granted only to union members.

50. Millis, op. cit. supra note 16, at 101; Gregory \& Katz, Policy Development UNDER THE NLRA, 25 (1947) ; Ward 1154 \& n.19, 1155-57.

51. In the Teamsters appeal, an employee in a nonunion shop had been demoted to the bottom of the seniority list for not paying his union dues. The Court ruled that such discrimination was invalid although the employee involved was perfectly free to quit the union and maintain his former position on the seniority list. 347 U.S. at 25-27. On a strict reading of "membership" it would be highly questionable to find that the discrimination in question either encouraged or discouraged union membership. Depending on the individual, it might do either one or neither. However, by reading "membership" broadly to include discrimination to compel "adherence to union rules and policies," the Court could easily decide that the seniority demotion encouraged union members to adhere to union rules, and infer that such was the intent of the demotion. The origin of the Court's expansion of section 8(a) (3) is not hard to find, for the right to refrain from adherence to union rules and policies is a reasonable interpretation of the section 7 right to refrain from self-organization and concerted union activities. The language of the opinion shows that such was the Court's actual ground of decision:

The policy of the Act is to insulate employees' jobs from their organizational rights. [Citing section 7.] Thus $\$ \S 8(a)(3)$ and $8(b)(2)$ were designed to allow employees to freely exercise their right to join unions, be good, bad or indifferent members, or abstain from joining any union without imperiling their livelihood. The only limitation [is the $8(a)(3)$ union shop] ....

Id. at 40.

52. See In re National Motor Bearing Co., 5 N.L.R.B. 409 (1938); In re Ford A. Smith, 1 N.L.R.B. 950 (1936) ; Ward, supra note 13, at 1170-71. For a discussion of what constitutes "just cause" for discharge, see $i d .1188-89$.

53. See, e.g., NLRB v. National Motor Bearing Co., 105 F.2d 652 (9th Cir. 1939); Port Gibson Veneer \& Box Co., 70 N.L.R.B. 319 (1946), enforced as modified, 167 F.2d 
Since the act of delegating control of hiring to the union affects all employees equally, it may be considered as an act similar to an employer lockout. The Board in Mountain Pacific, however, does not contend that the employer actually intended to encourage or discourage union membership as in a lockout. ${ }^{54}$ Nor does the Board contend that the mere act of employer delegation in and of itself naturally results in encouraging union membership. ${ }^{55}$ Rather, the Board argues that whenever unions receive control, "it is reasonable to infer" that they will administer the conditions of employment with the proscribed intent of encouraging membership..$^{56}$ The substance of the Board argument, therefore, is that the act of delegation, since it inevitably results in individual union acts of discrimination which indirectly constitute 8 (a) (3) violations, must itself violate 8 (a) (3). Whether such an inference is valid may be seriously questioned. The Board attempts to base this inference on Radio Officers. ${ }^{67}$ But while the Court there held that intent to encourage could be inferred from proven acts of disparate treatment whose natural consequences were to encourage union membership, it neither held nor intimated that the acts of disparate treatment themselves could be inferred. ${ }^{58}$ In fact, section 10 of the Taft-Hartley Act requires that Board findings be based on "the preponderance of the testimony taken," the word "preponderance" having been specially added in 1947 to end the Board's excess reliance on its expertise. ${ }^{59}$ Since by the Board analysis in Mountain Pacific those specific union acts which violate $8(\mathrm{a})(3)$ need not have occurred, or been proven, it may be argued that the mere act of delegating control over specific conditions of employment does not violate section 8 (a) (3). It follows that the prospective application of the Board's three conditions to all hiring halls also cannot be based on section $8(\mathrm{a})(3)$.

The Board's Mountain Pacific analysis falters because it attempts to prove too much. The decision seems to rest on a finding that discrimination actually does occur through the act of delegation. At the same time, however, the Board's opinion makes several references to the coercive atmosphere created by the unilaterally controlled hiring hall, ${ }^{60}$ implying that the real threat to section 7 rights here may not be the fact of discrimination, but rather the belief of employees that they will be discriminated against if they are not good union members, a belief based upon the mere existence of unilateral union control

144 (5th Cir.), cert. denied, 335 U.S. 819 (1948) ; NLRB v. Hopwood Retinning Co., 98 F.2d 97 (2d Cir. 1938); Note, 50 Colum. L. Rev. 1123 (1950).

54. A specific finding of such intent would bring the act of delegation within 8 (a) (3). See National Maritime Union, 78 N.L.R.B. 971 (1948); cf. In re Millfay Mfg. Co., 2 N.L.R.B. 919 (1937) ; In re Canvas Glove Mfg. Co., 1 N.L.R.B. 519, 526 (1936).

55. Such would be the case if standards were included in the contract of delegation which on their face were clearly designed to encourage membership.

56. 119 N.L.R.B. at 895.

57. Id. at 895-96.

58. See 347 U.S. $48-52$.

59. See Cox, stipra note 15, at 39-40.

60. 119 N.L.R.B. at 895-96. 
over hiring. This observation seems pertinent. If the prospective employee believes there is discrimination, he is just as effectively discouraged from exercising his section 7 rights not to join a union as if he were in fact discriminated against. Thus the existence of unilateral union control might be found to satisfy one test of an 8(a) (3) violation-encouragement of union membership. Unfortunately, it does not satisfy the initial test-that the employer must "discriminate." The Board attempted to overcome this obstacle by finding actual discrimination through the process of inference piled upon inference. Not only does this analysis fail to meet the test of 8(a) (3), but it also obscures the real reason for decision and thus blocks a rational attempt to formulate legal and yet workable hiring hall procedures.

The first requisite to making sense out of Mountain Pacific is to develop tools of analysis which can distinguish threatened discrimination from discrimination in fact. The Board might construe 8(a) (3)'s prohibition against "discrimination" to read "discrimination or the threat of discrimination." Then the underlying policy of Mountain Pacific might be expressed by saying that a delegation of complete hiring power to the union would so greatly induce nonunion workers to believe they would be discriminated against that it is per se illegal under $8(a)$ (3). This would be a clearer statment. It would also give the Board's doctrine a better chance of affirmance on review, for the finding of a "threat" will not be lacking in supporting evidence to the same extent as was the finding of actual discrimination. ${ }^{61}$ But $8(a)(3)$ does not say "threat of discrimination," and has not been explicitly extended this far. ${ }^{62}$ Moreover, since the finding of threatened coercion might easily be made a violation under another section, $8(\mathrm{a})(1)$, it might be profitable simply for analytical clarity to rely on that section rather than 8 (a) (3).

Section 8(a) (1) provides that it shall be an unfair labor practice for the employer "to interfere with, restrain, or, coerce employees in the exercise of the rights guaranteed in section 7."63 A similar provision forbidding the union

61. The lack of evidence to support the finding of actual discrimination was the basis of the Ninth Circuit's reversal of Monntain Pacific. NLRB v. Mountain Pacific Chapter, 270 F.2d 425 (1959). When this rule came before the First Circuit, the court assumed the necessary step from actual to threatened discrimination in order to uphold the rule against the Ninth Circuit's objection. NLRB v. Local 176, Carpenter's Union, 276 F.2d 583 (1st Cir. 1960).

62. Cases involving 8(a) (3) violations have generally been based on overt acts of discrimination. See cases cited notes $51-53$ supra. The meaning of the hiring hall cases on this point, see note 26 supra, is not clear, because, like other 8 (a) (3) cases, they always fortify the statutory basis of the violation by calling it an 8 (a) (1)-8(a) (3) violation, failing to make clear which section applies to the various possible elements of the unfair practice. Even the First Circuit decision, supra note 61, which makes a clear distinction between actual discrimination and the threat of discrimination, confuses the issue by labeling unilateral control an 8 (b) (1) -8 (b) (2) violation (the charge was against a union). Although all 8 (a) (3) violations may also violate the much broader prohibitions of $8(a)$ (1), it does not at all follow that the converse is true.

63. 29 U.S.C. $\$ 158$ (a) (1) (1958). 
"to restrain or coerce" employees in the exercise of these rights is contained in section $S\left(\right.$ b) (1) (A).$^{64}$ Since the rights of membership or nonmembership in a union are section 7 rights, any attempt to coerce employees to abandon those rights violates $8(a)(1)$. The distinguishing feature of $8(a)(1)$ in this respect is that it prohibits "coercion," not merely acts of discrimination. The test of coercion applied under this section has not been to look for specific acts of economic deprivation. The NLRB has found that inoffensive acts may be deemed coercive when they "reasonably lead employees to believe that economic reprisal may be visited upon them." " The reasonable belief criterion is in turn administered by examining the surrounding circumstances and background of the activity. The Supreme Court has stated that an employer speech, not coercive in itself, might be found so by the NLRB in the context of other acts and events which, taken together, would have a coercive impact on employees. ${ }^{B 6}$ Thus, unilateral union control of a hiring hall can be found coercive in violation of $S(a)(1)$ if the Board can find, from all the circumstances, that employees would normally expect to be discriminated against if they are not union members in good standing.

It is useful to look further into the factors which might be the basis for a finding of employee coercion in Mountain Pacific. The coercive impact of any institution will vary according to the ease with which the union or employer can carry out the threat of potential discrimination. Unilateral union control over a condition of employment differs considerably in this respect from the normal joint union-management control. When management administers job rights in the joint-control situation, any attempt to discriminate against union members is likely to be protested by the union through the grievance procedure. The tendency of either union or management to discriminate against nonunion employees is also curbed. Three factors appear to guard against such prounion pressures. First, it might be assumed that management will be opposed to any acts which tend to strengthen the union, ${ }^{67}$ although the existence of antiunion attitudes among present day employers is probably not as dependable a safeguard as it was in 1935. Second, the participation of the employer in jointcontrol administration may make the union hesitant to give up the rights of nonunion members for fear that the employer will regard the waiver as precedent, applicable to the rights of all workers. ${ }^{68}$ This factor, too, must be qualified, because it assumes that the right taken away from the nonunion employee is of some economic importance to the employer. When job conditions such as seniority are involved, it may not matter to the employer which

64. 29 U.S.C. $\& 158$ (b) (1) (A) (1958).

65. Blue Flash Express Inc., 109 N.L.R.B. 591 (1954) (dictum).

66. NLRB v. Virginia Electric \& Power, 314 U.S. 469, 479 (1941) ; accord, NLRB v. England Bros., 201 F.2d 395, 398 (1st Cir. 1953).

67. This may be the assumption, at least in part, behind the enactment of LMRA, $\$ 9$ (a), 29 U.S.C. $\$ 159$ (a) (1958), discussed in text at note 94 infra.

68. See Report of Comnittee on Improvenzent of Administration of Union-Management Agrcements, 50 Nw. U.L. Rev. 143, 155 (1955). 
of several qualified employees gets a particular job, and he may therefore have no reason to insist upon strict application of the precedent set by the deprivation of a nonunion employee's seniority rights. Despite these qualifications, the Taft-Hartley Act recognizes and attempts to utilize the employer as a protective force by granting the employee a right to bring his grievances directly to the employer. ${ }^{89}$ In the unilateral hiring hall, however, the employer has removed himself from the hiring process, and the individual stands alone against the union. The pre-Wagner Act hiring hall is reborn, the union becoming the unopposed employer with a desire to promote union membership instead of preventing it. ${ }^{70} \mathrm{~A}$ third factor which may limit the liklihood of discrimination in a joint-control situation is the tendency of such administration to proliferate rules and objective standards governing conditions of employment. Generally, these standards serve to assure nondiscriminatory treatment of all employees represented by the union. But more important in the context of union discrimination, they tend to make specific acts of discrimination stand out more clearly, so that legal sanctions such as unfair labor practice charges can more easily be brought to bear. Also, notoriety may stimulate activity on the employee's behalf by interested third parties, such as the employer or rival union groups. ${ }^{71}$ In the union hiring hall, however, a two-party bargaining process does not exist, with the result that disputes between the union and a single employee do not lead to negotiations, rules, and objective standards, but may be summarily and quietly decided by the union. ${ }^{72}$

The psychological effect of all these potential pressures on the dissident employee may be highly coercive, especially where there is extensive evidence, which there is in the case of hiring halls, that the union has not hesitated in the past to use this dominant position to discriminate wherever necessary to enforce union membership and adherence to union policies. ${ }^{73}$

This is not to imply that unilateral control of job rights is per se coercive. On the contrary, unilateral employer control is of necessity an accepted prac-

69. IMRA § 9(a), 29 U.S.C. \& 159 (a) (1958).

70. Prior to the Wagner Act the dissident employee had no effective means of adjusting his grievances. Alone he had no power to bargain, Commons \& ANDREws, PrInciples OF LABOR LEGISLATION 126 (1927), and where the employer was adamant his choice was to either accept the status quo or look for employment elsewhere, see U.S. STRIKE CoMn's, Report on the Chicago Strike of June-July, 1894, at xxvi (1894).

It was to check such power that the Wagner Act was enacted. See the statement of policy NLRA § 1, 49 Stat. 449 (1935), as amended, 61 Stat. 136 (1947), 29 U.S.C. § 151 (1958). The 1947 amendment extends the 1935 policy considerations with respect to employer practices to union practices having the identical effect. $C f$. HABER \& LEVINSON 65 .

71. See Summers, Individual Rights in Collective Agreenents: A Prelimisary Analysis, 9 Buffalo I. Rev: 239, 245 (1960) (effect of general rules) [hereinafter cited as Summers].

72. Without rules and objective standards there is no way to assure due process for the individual. Cf. Cox, stipra note 15 at 275; Summers 247; Turner Constr. Co., 110 N.L.R.B. 1860, 1861 (1954) (example of union discrimination behind a cloak of secrecy).

73. See Fenton, Union Hiring Halls Under the Taft-Hartley Act, 9 LAB. L.J. 505, 506-07 (1958). 
tice. ${ }^{74}$ If the fear of discrimination followed $a$ priori from the absence of countervailing forces against the party in power, exclusive employer control should be a per se violation of $\delta(a)(1)$ as well. However, the Board has found such $S(a)(1)$ violations against the employer only where, in the totality of the circumstances surrounding the challenged act or institution, a coercive impact is found. ${ }^{75}$ Unilateral control is undoubtedly an important element in the finding of coercion, for it negatives the existence of safeguards present in a joint-control situation. But other circumstances must provide the background for an inference that the power of unilateral control will be abused. Thus the finding of coercion in Mountain Pacific must be based not only on the fact of unilateral union control, but also upon evidence of the past history of hiring halls and the employee's general estimate of a union predisposition to discriminate based upon his knowledge of this history. Whether unilateral control over other institutions or conditions of employment is "coercive" will thus depend on the peculiar circumstances of the situation challenged.

\section{The Requirements for A Noncoercive Hiring Hall}

Hiring halls found coercive under section 8 (a)(1) can be permitted only if the appearance of discrimination can be eradicated. The conditions set forth by the NLRB seem in part directed at this task. The requirement of posting the hiring standards seems to have no purpose other than generating employee confidence in the hiring hall's fairness. That it will succeed in doing so, however, is doubtful. Further analysis will show that the employer's right to reject applicants and the written agreement not to discriminate will not effectively lessen instances of actual discrimination, or lead anyone to believe that the hall is fairly run. Confidence can be restored only if the hall is organized with genuine and well known safeguards against discrimination.

There are two points in the exercise of unilateral union control over hiring where discrimination may occur: (1) in the standards under which hiring is practiced; (2) in the administration of these standards. Employee remedies adequate to prevent discrimination at these points will remove the threat of discrimination.

\section{Standards}

The first safeguard against discriminatory administration is to ensure that there are detailed nondiscriminatory standards against which the administration of the hall may be measured. The Mountain Pacific requirement that the standards of hiring and referral be posted at the hiring hall is sensible and necessary. The natural tendency of unilateral control, assuming a propensity

74. Unilateral employer control of job rights (management prerogative) is also permissible when a bargaining representative exists. See NLRB v. American Nat'l Ins. Co., 343 U.S. 395 (1952).

75. See notes 65-66 supra and accompanying text. 
to discriminate, is to avoid detailed standards..$^{76}$ Without them, discrimination is easier to practice. The individual, unaware of decisions in other cases, may not even be sure he is being discriminated against, and proof is made close to impossible. ${ }^{77}$ The employee spends most of his time on jobs away from the hall, and necessary witnesses may be working all over a city.

The effectiveness of any required standards in counteracting discrimination depends upon their detail. This poses no inherent problems since rules of hiring and job classification prior to referral are capable of a mechanical exactitude far beyond many other conditions of employment. ${ }^{78}$ What detail should be required can be left to later cases, but it should be sufficient to cover all aspects of the normal every day operation of the hiring hall.

Given standards of sufficient detail, the NLRB is an adequate safeguard to ensure they are nondiscriminatory. Upon a complaint filed by an employee, the Regional Director, after a minimum of inquiry, can determine whether $8(a)$ (3) discrimination is likely under the posted hiring standards. This can be accomplished with neither cost nor fear of reprisal (assuming the complainant remains anonymous) on the part of the employee.

Mountain Pacific might be read to require that referral standards be included in the collective bargaining contract delegating unilateral control. ${ }^{70}$ Further, in some Board seniority cases following Pacific Intermountain, there is evidenced a hazily-conceived belief that unilateral union administration of seniority, under standards finding a colorable basis in the collective agreement, places the case in the normal joint-controlled area ${ }^{80}$-the union's action being

76. Summers 245 .

77. See practices listed in Rains 373; HABER \& Levinson 65. See also Turner Constr. Co., 110 N.L.R.B. 1860, 1861 (1954) (example of cloak which covers union policy of referral) ; Peterson Constr. Co., 106 N.L.R.B. 850 (1953) (degree of proof Board demands is high).

78. For a discussion of typical standards see Sherman, Legal Status of the Building and Construction Trades Unions in the Hiring Process, 47 GEo. L.J. 203, 215-21 (1958).

79. The language in Mountain Pacific which might be thought to support this opinion is :

Significantly, the contract is silent as to methods or criteria to be followed by the Union in performing its function as hiring agent ... for all the Employers know or care, the Union's purpose in selecting some and rejecting others may be ... matters which, were they the basis for direct employer selection, could constitute clear discrimination.

119 N.L.R.B. at 894-95.

80. Under Armour \& Co.; 123 N.L.R.B. 1157 (1959) the union may administer seniority provided there are colorable standards in the contract and the employer had access to the normal grievance procedure to settle disputes. If the employer acquiesces in the union settlement after a semblance of dispute, the parties are bargaining the interpretation of the contract. Id. at 1157 n.3. Carrol Freight Carriers Corp., 125 N.L.R.B. No. 54 (1960). If there are no such colorable standards, however, there is an invalid delegation. See cases cited note 32 supra.

Such logic chopping not only clouds the main issue, the possibility of administrative discrimination, but is illogical. Since the parties may bargain any new issue during the life of a contract, it is equally valid to argue that employer acquiescence in a union settle- 
"ministerial" and therefore valid.81 The nature of the hiring hall, however, would make such a requirement burdensome. A single hiring hall may have a dozen or so different contracts with independent employers. To require the hiring standards to be in the collective bargaining agreements would undoubtedly necessitate that they be in all the contracts and be identical. ${ }^{82}$ Considering that the agreements may well be negotiated at different times and run for different terms, the effect of the requirement would be to create great inflexibility in the operation of the hall because of the difficulty in changing all the contracts, or else would result in vague, broad standards allowing the very type of administrative discrimination they are intended to eliminate. Even where there is multi-employer bargaining of a single form contract, ${ }^{83}$ a certain amount of inflexibility or vagueness would still remain. ${ }^{84}$ There are also problems of grievance adjudication. When an individual is not referred by the hiring hall, no one employer can be singled out as responsible for protecting the victims. ${ }^{85}$ In other words, the attempt to treat the hiring hall as if it were in the normal collective bargaining area creates as many problems as it solves and may defeat, in the case of a standards requirement, the purpose of the requirement itself. ${ }^{86}$

The primary effect of not putting the standards in all the contracts may be that the union will be able to make arbitrary changes in hiring hall rules in order to discriminate against specific individuals. But even if the union succeeded in making retroactive changes, ${ }^{87}$ the device would be too cumbersome and blatant. When general rules are changed in order to discriminate, it is very difficult to restrict application to the intended victims. ${ }^{88} \mathrm{Also}$, such manipulation of standards would be easily spotted after a minimum of investigation, making recourse to the NLRB a simple and adequate remedy.

\section{Administration of Standards: Grievance Procedures and Section $9(a)$}

Assuming there are nondiscriminatory standards, discrimination may still occur in the administration of these standards. In such cases the Board remedy

ment of a seniority grievance is de novo bargaining during the term of the contract setting up new joint standards of seniority. Cf. NLRA $\$ 8$ (d), 29 U.S.C. $\$ 158$ (d) (1958) (which was intended to make bargaining during the contract term voluntary and not compulsory). A colorable contract provision is unnecessary to a spurious joint bargaining claim.

81. See Local 553, Teamsters Union v. NLRB, 266 F.2d 552 (2d Cir. 1959).

82. See text at note 98 infra.

83. See Comment, 60 YALE L.J. 673, 675 (1951) (bargaining in the construction industry).

84. See 11 Stan. L. Rev. 181, 185 (1958).

85. See text at note 98 infra.

86. The same problem occurs with respect to NLRB elections. Cf. Comment, 60 YALE L.J. 673, 690-94 (1951).

87. Under collective bargaining contracts, retroactive changes by management and the union are not permitted to deprive employees of rights already "vested." See Elgin, J. \& E. Ry. v. Burley, 325 U.S. 711 (1945); In re Norwalk Tire \& Rubber Co., 100 F. Supp. 706 (D. Conn. 1951) ; Report, supra note 68, at 150-53, 162. But see Summers 239-40.

88. Summers 245 . 
suggested above seems inapposite. While the Board may be expected to watch over standards applicable to all members of a hall, it is too great a burden to require the Board to follow up innumerable administrative disputes whose significance may not go beyond the single employee involved. ${ }^{89}$ Further, standards may be checked with a minimum of investigation, but a given dispute may require lengthy analysis of past practices in the hall, consuming an inordinate amount of expense, energy, and personnel on the part of the Board. While the Board might be relied on to step in where extensive evidence of a pattern of discrimination is unveiled, this protection is insufficient, for it requires only sporadic but well aimed discrimination to make examples of the uncooperative and to create the type of coercive atmosphere proscribed by 8 (b) (1).$^{90}$ Only a solution built into the structure of the hall, knowledgeable of the practices of the hall, and available on short notice is likely to remedy administrative discrimination.

The answer to disputes over contract administration in the normal industrial context is the grievance procedure. While one function of the grievance procedure is to provide for continued bargaining during the term of the contract, ${ }^{91}$ it is also used simply to prevent administrative variance from established contract standards. Provided an effective procedure could be devised to fit the hiring hall context, its general acceptance as a means of settling labor disputes indicates that it would be an adequate remedy to meet the threat of administrative discrimination.

What constitutes an "effective" grievance procedure for the protection of employees from union discrimination is not a new question. Congress has already attempted to provide an answer for the normal joint-control situation in section 9(a) of the Wagner Act. Section 9(a) states that "any individual employee... shall have the right at any time to present grievances adjusted without the intervention of the bargaining representative," provided that the settlement conforms to the contract and that the union may be present. ${ }^{02}$ Its purpose is to give the employee access to whatever normal collective grievance procedure there is, including the right to force arbitration should it exist. ${ }^{93}$ The section contemplates a background of an adversary grievance procedure where the employer and union resolve their conflicting interests. It then provides that the procedure is to be modified in a few cases to let the individual take the union's place when in his opinion the union unfairly refuses to process his grievance. ${ }^{94}$

89. Cf. Summers 251 (unions often will not process grievances for this reason).

90. See Rains 376-77; HABER \& LeVINSON 65 .

91. See, e.g., the discussion in United Steelworkers v. Warrior \& Gulf Nav. Co., 363 U.S. 574 (1960).

92. 29 U.S.C. $\$ 159$ (a) (1958).

93. See Hughes Tool Co., 56 N.L.R.B. 981 (1944), modified, 147 F.2d 69 (5th Cir. 1945).

94. Report, supra note 68, at 143-47; Sherman, The Individual and His GrievanceWhose Grievance Is It?, 11 U. PITT. L. REv. 35, 35-36 (1948). 
The literal meaning of section $9(\mathrm{a})$ is to allow the aggrieved employee to take his complaint to a presumably fair-minded employer. But since ninetyfour per cent of all collective bargaining contracts provide for arbitration as the final step of the grievance procedure, ${ }^{95}$ its practical effect is to give the dissident employee access to an impartial arbitrator as well. Although there is much debate about the enforceability and alienability of section 9 (a) rights, ${ }^{96}$ at least that section stands as evidence of congressional policy in this area and for that reason should be used as a guide in fashioning conditions under which unilateral hiring halls can escape the strictures of $8(a)(1)$.

Since section 9(a) was drafted with the joint-control situation in mind, several assumptions underlying the express language of the section are inapplicable to the unilaterally controlled hiring hall, and literal application of the statute to such hiring halls is impractical. The meaning of unilateral control is to remove disputes over hiring from the jointly administered grievance process. The aggrieved employee has no access to the employer, since the employer has waived his right to participate in the settlement of grievances.

It might be argued that section 9(a)'s policy would be satisfied if the hiring hall standards were made a term of the collective agreement, thereby making available an appeal to the employer and to the contractual grievance process. Unfortunately, little aid can be expected from the employer. The employer did not make the initial decision giving rise to the grievance. He has no interest, adverse or otherwise, or else he should not have delegated control. Also, employers in industries which utilize hiring halls are generally reluctant to challenge the union over minor disputes. ${ }^{97}$ And even if the employer professed an interest, the hiring hall is far from his place of business, he knows little about the operation of the hall, and his interference may do more harm than good.

Of course, employer impotency might be regarded as inconsequential if the aggrieved employee could thereafter gain access to the contractual arbitration

95. 2 BNA Collective Bargaining Negotiations and Contracts $\llbracket 51: 7$ (1960).

96. See text at notes 106-10 infra. For discussions of the legislative history of 9 (a), see Report, supra note 68, at 169-73, 1949 Wrs. L. REv. 154, 162-67; Sherman, supra note 94, at 45-47; Dunau, Employee Participation in the Grievance Aspect of Collective Bargaining, 50 Coluar. L. Rev. 731, 744-45 (1950).

97. The primary employer interest in the construction and maritime industries is to, respectively, complete the construction job and get ships with cargo on the seas. S. REP. No. 1827, 81st Cong., 2d Sess. 19 (1950). In the short run the employer will sacrifice all minor disputes to these ends, saving complaints for the -next bargaining session or occasional showdown fights. Such minor disputes are settled on the spot with the union busi-: ness agent under the threat of an immediate walkout, a fact which is evidenced by the almost complete absence of arbitration decisions in these industries. Compare Cumulative Digest and Index, Vol. 21-30, Lab. Arb. 963, 965 (1960) (in 1952-1958 period 11 construction industry arbitrations, 8 shipping and longshoremen's), with id. at 963-66 (e.g., 270 for steel industry). See also Ryan, Industrial Relations in the San Francisco BuIlding Trades 103-34 (1935) (examples of union power); Haber \& Levinson 47-48, 163. 
process. On its face, this remedy would seem to satisfy section 9(a)'s demand for an impartial referee between the individual and the union. But the peculiar facts of hiring hall operations would make this remedy less effective for the individual, and would also burden the hiring hall operation itself.

The effect of discrimination at a hiring hall is that the employee is not sent to any one of perhaps a dozen employers. Which employer does the injured employee pick? Which contract does he sue under? Which established grievance procedure is the appropriate one? Perhaps the employee would be free to bring the grievance under any contract. While this procedure might reduce his fear of discrimination, it would also create a multiplicity of different interpretations of the hiring hall standards, impossibly complicating administration of the hall. The hiring hall must handle a continuous flow of job opportunities from different employers, and must assign them to workers according to some standard. Anything but a uniform standard for all jobs and all employees, applied and interpreted at the hall, would probably produce much confusion. Apart from the institutional inconvenience, ${ }^{98}$ such confusion might also furnish a smokescreen behind which the union can discriminate without detection. Even without these particular difficulties, the practice of putting hiring standards in the contract has been questioned above on other grounds, namely that it prevents the formulation of detailed and yet flexible standards which are the first condition of nondiscriminatory hiring. ${ }^{99}$

Although literal compliance with section 9 (a) is impracticable, the policy underlying that section might still be implemented in solving the problem of the unilateral hiring hall. The thrust of that policy is to protect the individual from union discrimination by giving him independent access to a meaningful grievance procedure. The task, then is to devise such a grievance procedure tailored to the peculiar problems and operational requirements of the hiring hall.

For reasons already pointed out, the only practical solution is to have a single grievance procedure at the hall. The initial steps in the procedure should be handled by the union alone, concluding with a union board responsible for interpreting or elaborating the rules of the hall. This is dictated by practical considerations. The normal collective bargaining grievance adjudication is more than a simple matter of contract interpretation; it may involve considerable de novo bargaining to cover unforeseen situations. ${ }^{100}$ There is no such bargaining function for the hiring hall grievance procedure. By the original delegation of unilateral control, the union may pick whichever of two possible interpretations of its own rules it prefers, or formulate any desired new rule to cover unforeseen situations as they occur. The only function of the grievance procedure is to make sure that the settlement of the grievance

98. The administrative confusion alone assures that no union would permit an agreement providing for arbitration through the normal collective bargaining procedure.

99. See text at notes 79-86 supra.

100. United Steelworkers v. Warrior \& Gulf Nav. Co., 363 U.S. 574 (1960). 
is nondiscriminatory and conforms with whatever rules and past practices there are. Therefore, the union should have ample opportunity to clarify its position prior to submission of the dispute for final settlement.

Final appeal must be to an impartial third party. This is the practical meaning of 9 (a) in the joint-control area, and is the only kind of appeal which would satisfy $8(a)(1)$ in negating the threat of discriminatory administration. Therefore, unresolved disputes between an individual and the union should be submitted to an arbitrator acceptable to them both. ${ }^{101}$ Although the union may complain that such procedures will lead to union harassment, an appropriate cost allocation for final appeal should discourage frivolous claims. ${ }^{102}$

Arguably, another solution would be a mixed review board, composed of management and union representatives. Such boards are common to the hiring hall set up in the maritime industries, where due to industry-wide bargaining, joint-control halls are often set up, run by the union with appeal to a mixed board. ${ }^{103}$ The impartiality of such mixed boards is questionable, however, especially in light of the employer lack of interest when complete control is delegated initially to the union. ${ }^{104}$ Moreover, in many of the casual labor industries the employers are so removed from the actual operation of the hall that in all probability they cannot contribute intelligently to the appeal process. A tripartite board consisting of employer, union and third-party would be ineffective for the same reasons. ${ }^{105}$

\section{An Objection}

The preceding analysis has been based on the premise that section 9 (a) grants the employee a right which may not be waived by an agreement between the employee and the union. Professor Cox and others have maintained, however, that to consider 9 (a) as granting an unwaivable statutory right would seriously interfere with the normal collective bargaining process. ${ }^{100} \mathrm{He}$ argues that it is necessary to sacrifice the 9 (a) right to the needs of collective bargaining, ${ }^{107}$ a view which might also apply in defining the

101. Allowing individuals access to arbitrators is common in other countries and has been adopted by railroads. Summers $253-54$. For different solutions to the picking of arbitrators, see $i d$. at 253 ; Report, supra note 68 , at $182,184-86$; Dunau, supra note 96, at $751-54$.

102. See Report, supra note 68, 184; Summers 251.

103. See 2 BNA Collective Bargaining Negotiations and Contracts If 87:486 (1960).

104. See generally text at note 96 supra.

105. This plan is suggested in Sherman, supra note 78, at 216-17. .

106. Cox, Rights Under a Labor Agreenent, 69 HARv. L. REv. 601, 621-24 (1956); Silver, Rights of Individual Employees in the Arbitral Process, N.Y.U. 12TH ANN. Conf. on Labor 53 (1959). See also 93 Cong. REc. 3702 (1947).

The law on this point is unclear. See Report, supra note 68 , at $152 \& \mathrm{nn} .32-35,178-79$ \& n.136; Sherman, supra note 94, at 51-54.

107. Cox, supra note 106, at 630-34 (Prof. Cox recognizes the danger of discrimination, sets out several alternative means of protection, and rejects them all); see Silver, supra note 106 , at 55 . 
scope of an underlying $8(a)(1)$ violation, since it attempts to define the amount of coercive pressure which must be tolerated to preserve other values. Were this position to prevail it might be argued that, if the individual may be denied access to the grievance procedure in the joint-control situation, why not also in the hiring hall? Let the individual suffer except in the flagrant case where he can get the attention of the Board.

The arguments in favor of this position, however, do not have merit with respect to unilateral union control. Instead, they are based on the problems of bargaining in a joint-control situation. Professor Cox argues that most of the difficult problems which arise in grievance adjudication are not merely questions of contract interpretation, but are situations where additional bargaining must take place to adapt the agreement to the new problem. The individual, he argues, has no right to bargain in this way for the whole group. ${ }^{108}$ Also, in the case where a solution will change the relative job standing of several groups of employees, a solution satisfactory to the individual may jeopardize the union's representative position of these other employees. ${ }^{109}$ Finally, the balance of power between union and management may be such that the union must back down on certain valid grievances to maintain its bargaining position in areas more crucial to the bargaining unit. All these examples, however, assume an administrative decision on the part of management over which the union has no control and which compromises the union's interests as bargaining representative. The union must then weigh the solution it desires and the feasibility of its negotiation. The individual's intrusion is harmful because it deprives the union of freedom to maneuver in bargaining with the employer. In the unilateral control situation, on the other hand, the employer has waived his interest. The initial decision giving rise to the grievance is made by the union itself. And while the employee, through arbitration, will be able to bind the union to existing hiring standards, the union remains free to amend the rules prospectively and give a binding initial interpretation to ambiguous provisions. ${ }^{110}$ Thus, while Professor Cox's position may have merit with respect to the joint-control area, it has no applicability to unilateral union control over hiring.

\section{Right to Reject}

The inclusion of the right of the employer to reject union referrals as one of the conditions in Mountain Pacific is nowhere explained by the Board.

108. Cox, supra note 106 , at 606-16, 625-27. See also Dunau, supra note 96, at 732-34.

109. Cox, sipra note 106 , at $611-12$; see Pierson, Collective Bargaining Systems 10-11 (1942).

It is also argued that 9 (a) would lead to a loss of union prestige where the individual bypasses the union or the employer favors individually pressed grievances. Report, supra note 68 , at 164-65; Cox, supra note 106, at 629 . This has no relevance in the unilateral hiring hall, since the employer need not be involved at all.

110. It might also be noted that the employee gets considerable protection in the jointcontrol area even without a right to prosecute his grievance. See text at notes 67-71 supra. 
On the one hand, it may be necessary to protect the employer's so-called hiring prerogative. ${ }^{111}$ Whether such a right should exist does not involve questions of employee coercion or discrimination and so are beyond the scope of this Comment. On the other hand, it may be felt that the right to reject will give the employee some measure of security in the belief that the employer possesses a weapon with which he may insist upon standards of meritorious qualifications. In actual fact, however, the right to reject is easily adapted to employer-union collusion for avoiding the other requirements of Mountain Pacific. If the employer is induced to reject nonmember applicants, or those on the outs with the union, discrimination and coercion are again introduced by use of a practice required and condoned by the Board. The fact of collusion would be very hard to establish, and one commentator has already suggested that it will be the inevitable means of avoiding Mountain Pacific in the construction industry. ${ }^{112}$ If such is the case, the right to reject surely should not be depended on as a means of protecting the employee.

\section{Section $8(f)-A$ New Statutory Solution?}

It might be argued that the 1959 amendment of the Taft-Hartley Act adding section $S(f)$, validating union referral of job applicants in the construction industry, ${ }^{113}$ would obviate the necessity that unions in this industry, and perhaps by analogy, in every other industry, comply with the conditions laid down in Mountain Pacific or suggested in this Comment. There are, however, two important provisos to section $8(f)$ which make clear that the analysis herein is by no means superseded by passage of this section. The section validates an agreement with a labor organization of which the employees are members, adding the parenthetical proviso that the union is not to be "established, maintained, or assisted by action defined in subsection (a) of this sec-

Since these institutional safeguards are not available in the unilateral control situation, there is another reason for not applying the Cox position to hiring halls.

111. See notes 44-45 supra and accompanying text.

112. Rains 370.

113. 73 Stat. 545 (1959), 29 U.S.C. $\$ 158(f)$ (Supp. I, 1959) :

It shall not be an unfair labor practice . . . for an employer engaged primarily in the building and construction industry to make an agreement covering employees engaged (or who, upon their employment, will be engaged) in the building and construction industry with a labor organization of which building and construction employees are members (not established, maintained, or assisted by any action defined in section 8(a) of this Act as an unfair labor practice) because ... (3) such agreement requires the employer to notify such labor organization of opportunities for employment with such employer, or gives such labor organization an opportunity to refer qualified applicants for such employment, or (4) such agreement specifies minimum training or experience qualifications for employment or provides for priority in opportunities for employment based upon length of service with such employer, in the industry or in the particular geographical area: Provided, That nothing in this subsection shall set aside the final proviso to section $8(a)$ (3) of this Act.... 
tion (section 8) as an unfair labor practice."114 The section then finally provides that nothing in the standards of referral shall abrogate the proviso to 8 (a) (3) that in a union shop discrimination is valid only for the nonpayment of union dues. In other words, to prevent a violation of section $8(a)$, the operation of the hiring hall must in no way discriminate in violation of 8 (a) (3) to encourage membership_- "maintain or assist" membership in the language of $8(f)$ - or enforce compliance with union rules and policies, the usual interpretation given to the 8 (a) (3) union shop proviso. ${ }^{115}$ It also appears that a coercive threat of discrimination, normally a violation of 8 (a)(1), would still be a violation under the new section, for such coercion can certainly be said to "maintain or assist" a union "by action defined in [8(a)] as an unfair labor practice." Legislative history supports this conclusion, for the joint committee report states that the section was not intended to overrule the Mountain Pacific doctrine. ${ }^{116}$ Furthermore the language of the third proviso phrases the allowable hiring hall contract narrowly, permitting the union to contract for "an opportunity to refer qualified applicants."117 The hiring hall conditions herein suggested do no more than to remedy existing unfair labor practices and are thus unaffected by the passage of this section.

114. Ibid.

115. See Radio Officers' Union v. NLRB, 347 U.S. 17, 44-45 (1954).

116. H.R. Rep. No. 1147, 86th Cong., 1st Sess. 42 (1959).

117. See note 113 supra. 